\title{
Carcinoma Caecum coexistent with Tuberculosis : a case report
}

\author{
L. Jaichand Singh
}

\begin{abstract}
Abstrak
Lesi tuberkulosis dapat terjadi bersamaan dengan keganasan sehingga menyulitkan diagnosis. Satu kasus karsinoma usus besar yang bersamaan dengan lesi tuberkulosis di tempat yang sama dilaporkan. Pasien telah menyelesaikan terapi anti tuberkulosis dan saat ini sedang menjalani kemoterapi reguler. Sampai saat ini keadaan umum pasien baik. (Med J Indones 2005; 14: 128-30)
\end{abstract}

\begin{abstract}
Tubercular lesion may coexist with malignancy in various sites resulting in difficulties in diagnosing the conditions. A case of carcinoma caecum associated with tubercular lesion in the same site is reported. The patient have completed the antitubercular therapy and is now on regular anticancer chemotherapy. Till now the patient is doing fine. (Med J Indones 2005; 14: 128-30)
\end{abstract}

Keywords: Carcinoma Caecum, Intestinal Tuberculosis, Management

Tubercular lesion may coexist with malignancies in various ways. The most common association being pulmonary tuberculosis associated with malignancies at various sites. In developing countries where tuberculosis is rampant the association may be either in the same organ or different organs. But the association of the two diseases in the same site is not a common finding.

\section{Case report}

A 53 year old widow reported with history of chronic constipation along with off and on pain over the right iliac fossa with acute intense pain for the last one month. A firm globular tender lump was palpated over the right iliac fossa. Patient was managed symptomatically. After a period of two weeks a firm nontender lump was felt over the same site, which on cytology proved to be adenocarcinoma. The routine haematological and biochemical investigations revealed mild anaemia and low serum albumin. The barium

Department of Radiotherapy, Regional Institute of Medical Sciences, Imphal - 795004, India enema (double contrast) and colonoscopic examination revealed a mass in the caecum partially occluding the lumen. The colonoscopic biopsy was however not conclusive. Metastatic workup did not revealed any lesion. With these findings a diagnosis of carcinoma caecum was entertained and she was put up for right hemicolectomy. On laparotomy a growth of $7 \times 5 \mathrm{cms}$ was found in caecum adherent to the posterior peritoneum with a central abscess within the growth which has obliterated the lumen partially. Histopathological report revealed colloid carcinoma with granulomatous Koch's lesion in the colonic wall (Fig.1 \& 2). There was no metastatic or granulomatous deposits in the lymph nodes resected. Intrabdominal operative assessment of the liver and other organs were found to be normal. The serum carcino-embryonic antigen (CEA) level was 1.42 $\mathrm{ng} / \mathrm{ml}$. The patient was then diagnosed to be suffering from carcinoma caecum along with intestinal Koch's and was started on 6 months antitubercular 4 drugs regime along with anticancer chemotherapy - Inj 5 Flurouracil-750 mg and Inj Leucovorin $100 \mathrm{mgm}$ days $1-5$ every four weeks. Till now she is doing well and had completed the antitubercular treatment and has completed 12 months of anticancer chemotherapy. The last CEA at $12^{\text {th }}$ month showed a value of $0.35 \mathrm{ng} / \mathrm{ml}$. 


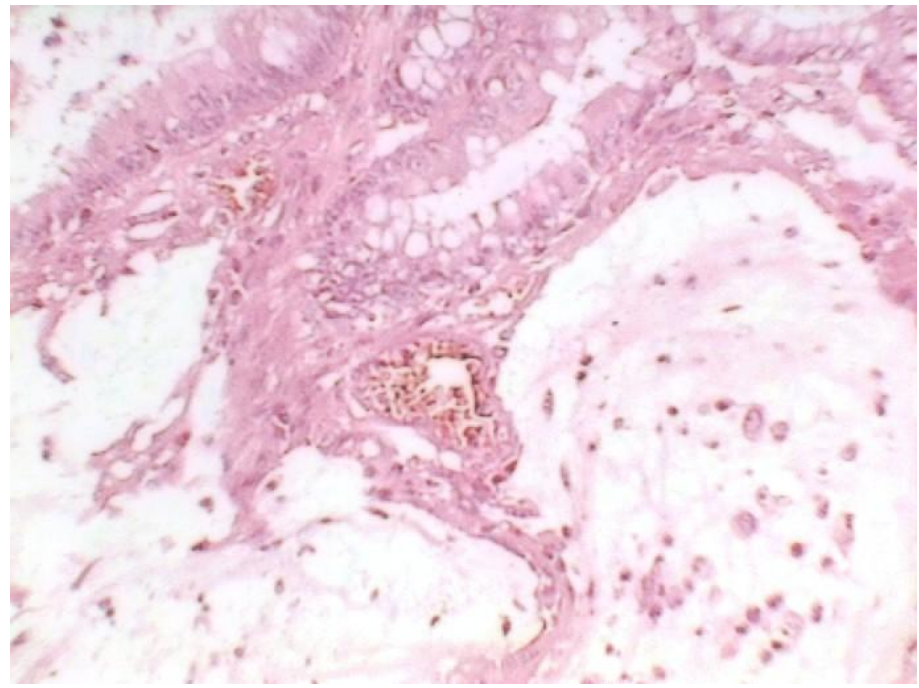

Figure 1. Microphotograph showing Well Differentiated Adenocarcinoma with pool of mucin (H\&E, X 40)

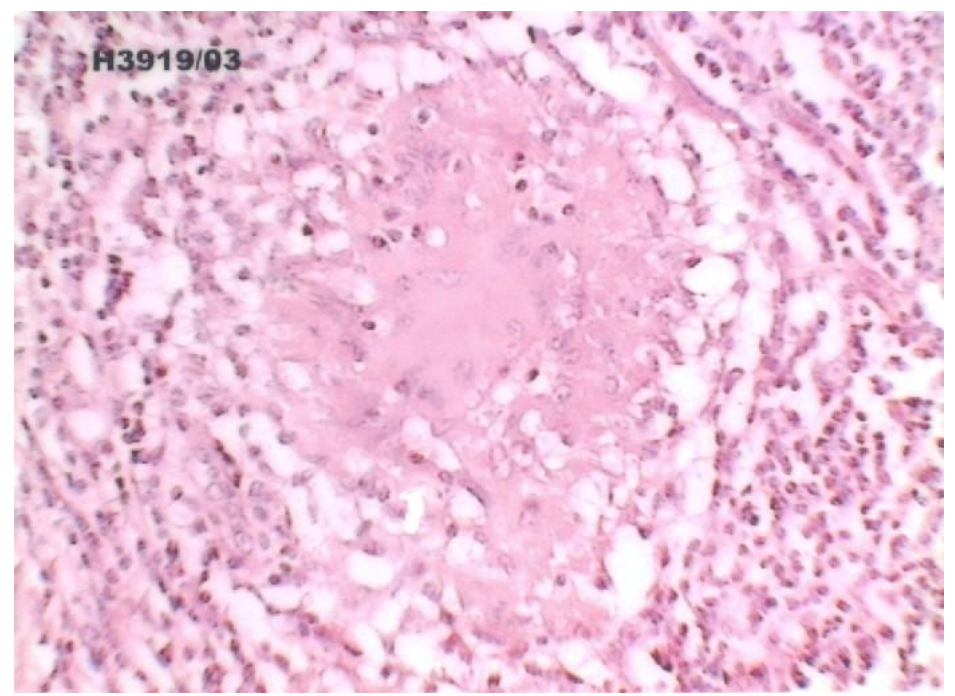

Figure 2. Microphotograph showing well defined epitheloid granuloma with early central caseous necrosis (H\&E, X 40) 


\section{Discussion}

Tuberculosis can be associated with various types of malignancy. The commonest association being the pulmonary tuberculosis. However association of extra pulmonary tuberculosis and malignancy in the same site is comparatively rare.

Occurrence of extra pulmonary tuberculosis is commonly seen in an endemic region like India. It is one of the most common causes of ulceroconstrictive lesions of the intestine seen most commonly in Ileocaecal region probably due to stasis. ${ }^{1}$ The exact aetiopathological relationship between the two diseases is still debatable. But some workers have raised the doubt of the ulcerative lesions of the tuberculosis to be the precursor of the carcinoma. It may be due to the chronic inflammatory process with unsuccessful or incomplete healing and consequent regeneration. $^{2}$

A study from India found the association to be more common in the females involving the right colon. Histopathologically mucinous type was the predominant finding. They have also hinted a link between the two separate lesions. ${ }^{3}$ Similar findings were seen in another Japanese study. ${ }^{4}$ A study from Australia showed a better outcome in these patients as compared to nontuberculous colon cancer. They were of the opinion that the increased immunity against tubercle bacilli might be a contributory factor to the better outcome. ${ }^{5}$ But it requires further study.

Though Mycobacterium tuberculosis may not be demonstrated in the biopsy materials, presence of caseous necrosis is considered an important criterion for diagnosis of intestinal tuberculosis. Wig et al could demonstrate acid fast bacilli only in 14 out of 37 cases by culturing the biopsy materials, though on Ziehl Neelsen staining all sections were negative for acid fast bacilli. ${ }^{6}$

As in our patient, there is every possibility of missing either of the lesions on cytology. There may be occasions in some patients that we detect only the tubercular lesions on cytology and choose to manage the patient conservatively overlooking the associated malignancy. It is therefore advisable that all colonic tuberculoma lesions should be subjected to colonoscopy and resectional surgery if feasible for three main specific reasons - early response to antitubercular therapy, to avoid intestinal obstruction due to fibrosis on healing, and not to miss the coexisting malignancy if any.

\section{Conclusion}

A rare lesion of coexistent Adenocarcinoma and Tubercular lesion involving the caecum is reported. The possibility of missing either of the lesion on preoperative investigations is to be kept in mind. The resectional surgery wherever possible is emphasised. The claim of better outcome of such double lesions over non tubercular colon cancer requires further attention and study.

\section{References}

1. Maheshwari V, Alam K, Indu, Tyagi SP. Ileocaecal tuberculosis associated with Adenocarcinoma of the caecum. JIMA 1995; 93: 392-3.

2. Maruta K, Tanaka S, Nakamura T, Hagio S, Sato E, Nishi M. Carcinoma of the colon coexisting with tuberculosis report of 2 cases. Gan No Rinsho 1983; 29: 448 - 53.

3. Jain BK, Chandra SS, Narsimhan R, Ananthakrishnan N, Mehta RB, Coexisting tuberculosis and carcinoma of the colon. Aust NZ J Surg 1991; 61: 828 - 31.

4. Tanaka K, Kondo S, Hattori F, Yamashita Y, Matsuda M. Itoh $\mathrm{K}$, et al. A case of colonic carcinoma associated with intestinal tuberculosis and an analysis of 26 cases reported in Japan. Gan No Rinsho 1987;33: 1117 - 23.

5. Goulston E. Colorectal cancer-tuberculosis connection. Med J Aust 1981;13: 637-8.

6. Wig KL, Chitkara NL, Gupta SP, Kishore K, Manchanda RL. Ileocecal tuberculosis with particular reference to isolation of Mycobacterium tuberculosis with a note on its relation to regional ileitis ( Crohn's Disease ). Am Rev Respir Dis 1961; 84: 169 - 78 . 